\title{
Growth and yield attributes of canola varieties under different seed rates
}

\author{
Muhammad Jawad ${ }^{1}$, Muhammad Islam ${ }^{2 *}$, Bilal Khan ${ }^{1}$, Anjum², Zahid \\ Hussian ${ }^{1}$, Wajid Ali Shah ${ }^{1}$, Roohul Amin ${ }^{1}$, Jamshad Ali ${ }^{1}$, Muhammad \\ Ishaq $^{1}$ and Anees Ur Rehman ${ }^{1}$ \\ 1. Department of Agronomy, Bacha Khan University, Charsadda-Pakistan \\ 2. Department of Agronomy, The University of Agriculture, Peshawar-Pakistan \\ *Corresponding author's email: islamswati439@yahoo.com \\ Citation \\ Muhammad Jawad, Muhammad Islam, Bilal Khan, Anjum, Zahid Hussian, Wajid Ali Shah, Roohul Amin, Jamshad \\ Ali, Muhammad Ishaq and Anees Ur Rehman. Growth and yield attributes of canola varieties under different seed \\ rates. Pure and Applied Biology. Vol. 6, Issue 3, pp864-870. http://dx.doi.org/10.19045/bspab.2017.60091
}

Received: 20/03/2017

Revised: $13 / 07 / 2017$

Accepted: $18 / 07 / 2017$

Online First: $21 / 07 / 2017$

\section{Abstract}

A field experiment was conducted at Bacha Khan University Agricultural Research Farm, Bacha Khan University Charsadda, during winter-2015 to determine the growth and yield attributes of canola varieties under different seed rates. Four seed rates $\left(4,6,8\right.$ and $\left.10 \mathrm{~kg} \mathrm{ha}^{-1}\right)$ and two varieties (Durr-e-NIFA and Zahoor Swati) were tested in the experiment. The experiment was laid out in a randomized complete block design with three replications. Net plot size was $3 \mathrm{~m} \mathrm{x}$ $2 \mathrm{~m}$ having 5 rows with row to row distance of $40 \mathrm{~cm}$. Recommended dose of NP $\left(60 \& 75 \mathrm{~kg} \mathrm{ha}^{-}\right.$

${ }^{1}$ ) was applied. All the $\mathrm{P}$ was applied at sowing time while $\mathrm{N}$ was applied in split doses (Half at the time of sowing and the remaining half in first irrigation). All other agronomic practices were equally maintained for all plots. The results showed that maximum emergence $\mathrm{m}^{-2}(97)$, days to maturity (165), plant height $(149 \mathrm{~cm})$, biological yield $\left(3709 \mathrm{~kg} \mathrm{ha}^{-1}\right)$ and grain yield $(2170 \mathrm{~kg}$ $\mathrm{ha}^{-1}$ ) was produced at seed rate of $10 \mathrm{~kg} \mathrm{ha}^{-1}$. Maximum 1000-grains weight (3.92 $\mathrm{g}$ ) was produced at the seed rate of $4 \mathrm{~kg} \mathrm{ha}^{-1}$. Maximum emergence $\mathrm{m}^{-2}(82)$ was recorded for the variety Zahoor Swati. The variety Durr-e-NIFA produced maximum plant height $(145 \mathrm{~cm})$ and 1000grains weight (3.69 g). Biological yield $\left(3751 \mathrm{~kg} \mathrm{ha}^{-1}\right)$ and grain yield $\left(2228 \mathrm{~kg} \mathrm{ha}^{-1}\right)$ increased with increasing seed rate from 4 to $10 \mathrm{~kg} \mathrm{ha}^{-1}$ in case of Durr-e-NIFA variety.

Keywords: Canola varieties; Seed rates; Growth and Yield attributes

Introduction

Canola (Brassica napus L.) belongs to the family Brassicaceae. It is the most important source of vegetable oil in the world including Pakistan. Its leaves and stem also provide good quality forage yield to livestock $[1,2]$. The seeds of canola contain $40-45 \%$ oil and $36-40 \%$ protein. Its oil and meal are now acceptable as alternatives to soyabean oil and meal $[3,4]$. Canola oil has lower level of saturated fats (only 6\%) than any other edible vegetable oils [5]. Canola oil is better for human health because of its lowest content of saturated fatty acids among vegetable oils and moderate content of poly-unsaturated fatty acids [6]. In Pakistan, canola was grown on an area of 215.4 thousand hectares with a total production of 178.8 thousand tons. Its average yield was $830 \mathrm{kgha}^{-1}$, while in 
Khyber Pakhtunkhwa, it was grown on an area of 16.7 thousand hectares with a production of 7.3 thousand tons with an average yield of $437 \mathrm{~kg} \mathrm{ha}^{-1}$ [7]. Seed rate is an important factor for optimum plant population. The establishment of an adequate and uniform canola stand is critical to achieve high grain yield and grain oil content. Seed yield of canola is a function of population density, number of pods plant ${ }^{-1}$, number of seeds $\operatorname{pod}^{-1}$ and seed weight. However, yield structure is variable and adjustable across a wide range of populations [8]. Seed rates significantly affects days to maturity, siliques $\mathrm{m}^{-2}$, grains silique $^{-1}$, thousand grains weight, grain yield and oil percentage [9]. Increase in the seed rate up to $8 \mathrm{~kg} \mathrm{ha}^{-1}$ resulted maximum seed yield [10]. Increase in the seed rate beyond 8 $\mathrm{kg} \mathrm{ha}^{-1}$ declined number of pods plant ${ }^{-1}$ and number of seeds pod ${ }^{-1}[11]$.

Variety selection as per agro-climatic conditions of the locality is very important. Canola varieties vary significantly for many characteristics like seed yield, oil yield, number of pods plant ${ }^{-1}$, number of seeds $\operatorname{pod}^{-1}$ [12]. Some varieties are tall while others are dwarf due to their genetic potential [13]. Similarly a variation has also been found in number of branches plant ${ }^{-1}$ [14]. Disease resistance, seed quality, vigorous growth and development are other important characteristics which have never been ignored in variety selection for a locality. No variety contains all the required characteristics, but the basic pre-requisites in cultivar selection are lodging, disease resistance, yield and yield related attributes. So selection of desirable varieties is an important economic and management decision for a specific locality [15]. Keeping in view the increasing demand of vegetable oils, the present study was therefore conducted to determine the effects of different seed rates and varieties on growth and yield attributes of newly evolved high yielding varieties of canola.

\section{Materials and methods}

A field experiment was conducted at Bacha Khan University Agricultural Research Farm, Bacha Khan University Charsadda, Khyber Pakhtunkhwa-Pakistan during the winter season 2015-16. The objective of the experiment was to investigate the effect of seed rates and varieties on growth and yield components of canola in the agro-climatic conditions of Charsadda. Four seed rates (4, 6, 8 and $10 \mathrm{~kg} \mathrm{ha}^{-1}$ ) and two canola varieties (Durr-e-NIFA and Zahoor Swati) were tested in the experiment. The experiment was laid out in a randomized complete block design with three replications. Net plot size was $3 \mathrm{~m} \times 2 \mathrm{~m}$ having 5 rows $40 \mathrm{~cm}$ apart. The recommended dose of NP $(60 \& 75 \mathrm{~kg}$ $\mathrm{ha}^{-1}$ ) was applied. All the $\mathrm{P}$ was applied at sowing time, while $\mathrm{N}$ was applied in split doses (half at the time of sowing and the remaining half with first irrigation). All other agronomic practices were equally maintained for all plots. Data were recorded on emergence $\mathrm{m}^{-2}$, days to physiological maturity, plant height, 1000-grains weight, biological yield and grain yield. Emergence $\mathrm{m}^{-2}$ was recorded by counting the number of seedlings in three central rows, each row one meter long in three different places in each plot and the counts were averaged and converted in to number of seedlings $\mathrm{m}^{-2}$ by using the following formula:

Emergence $\mathrm{m}^{-2}=$ Total no. of seedlings emerged $\mathrm{R}-\mathrm{R}$ distance $(\mathrm{m}) \mathrm{x}$ row length $(\mathrm{m}) \mathrm{x}$ No. of rows Data for days to physiological maturity were counted from the date of sowing to the date when the color of $80 \%$ siliques turned from green to brown in each plot. Plant height was recorded by measuring the height of 10 randomly selected plants from ground level to the top of the plant in each plot at physiological maturity and then their average was calculated. For thousand grains weight, 1000 grains were counted from grain lot of each plot and weighed with the help of 
electronic balance. Biological yield was calculated after harvesting three central rows in each plot at maturity and dried and Biological yield $\left(\mathrm{kg} \mathrm{ha}^{-1}\right)=$ Biological yield in three central rows $(\mathrm{kg}) \times 10000$

$\mathrm{R}-\mathrm{R}$ distance $(\mathrm{m}) \mathrm{x}$ row length $(\mathrm{m}) \mathrm{x}$ No. of rows

Grain yield was calculated by weighing grains of three central rows in each plot and then converted to $\mathrm{kg} \mathrm{ha}^{-1}$ using the following formula

Grain yield $\left(\mathrm{kg} \mathrm{ha}^{-1}\right)=$ Grain yield in three central rows $(\mathrm{kg}) \times 10000$

$\mathrm{R}-\mathrm{R}$ distance $(\mathrm{m}) \mathrm{x}$ row length $(\mathrm{m}) \mathrm{x}$ No. of rows

\section{Statistical analysis}

The data recorded were analyzed statistically using analysis of variance techniques appropriate for randomized complete block design. Significant differences among treatments were determined using least significant difference (LSD) test for main as well as interaction effects [16].

\section{Results}

\section{Emergence $\mathbf{m}^{-2}$}

Data regarding emergence $\mathrm{m}^{-2}$ of canola as affected by seed rates and varieties are shown in Table 1. Seed rate and varieties had significant effect on emergence $\mathrm{m}^{-2}$ while the interactive effect of $\mathrm{S}$ and $\mathrm{V}$ was found non-significant. Maximum emergence $\mathrm{m}^{-2}$ (97) was observed with the seed rate of $10 \mathrm{~kg} \mathrm{ha}^{-1}$ while minimum emergence $\mathrm{m}^{-2}$ (61) was recorded with the seed rate of $4 \mathrm{~kg}$ $\mathrm{ha}^{-1}$. In case of varieties, maximum emergence $^{-2}$ (82) was observed in Zahoor Swati as compared to Durr-e-NIFA (77).

Table 1. Emergence $\mathbf{m}^{-2}$, days to physiological maturity and plant height of canola as affected by seed rates and varieties

\begin{tabular}{|c|c|c|c|}
\hline Treatments & Emergence $\mathbf{m}^{-2}$ & Days to maturity & Plant height $(\mathrm{cm})$ \\
\hline \multicolumn{4}{|c|}{ Seed rate (S) (kg ha-1) } \\
\hline 4 & $61 d$ & $162 b$ & $138 \mathrm{c}$ \\
\hline 6 & $71 \mathrm{c}$ & $162 b$ & $141 b c$ \\
\hline 8 & $88 b$ & $162 b$ & $144 \mathrm{ab}$ \\
\hline 10 & $97 \mathrm{a}$ & $165 a$ & $149 \mathrm{a}$ \\
\hline LSD value & 5.947 & 1.235 & 5.281 \\
\hline \multicolumn{4}{|c|}{ Canola varieties (V) } \\
\hline Durr-e-NIFA & $77 b$ & 162 & $145 \mathrm{a}$ \\
\hline Zahoor Swati & $82 \mathrm{a}$ & 163 & $141 b$ \\
\hline LSD value & 4.205 & $\mathrm{Ns}$ & 3.734 \\
\hline \multicolumn{4}{|c|}{ LSD value for interaction } \\
\hline $\mathrm{S} \times \mathrm{V}$ & Ns & Ns & Ns \\
\hline
\end{tabular}

Means in the same category followed by different letters are significantly different at $\mathrm{P} \geq 0.05$ levels. $*=$ significant Ns = non-significant

\section{Days to physiological maturity}

Table 1 shows the effect of seed rates and varieties on days to maturity of canola. Statistical analysis showed that seed rates significantly affected days to maturity, while varieties and the interaction of $\mathrm{S}$ and $\mathrm{V}$ had non-significant effect on days to maturity. Among seed rates, $10 \mathrm{~kg} \mathrm{ha}^{-1}$ took maximum days to maturity (165), while minimum day to maturity (162) were taken by $4 \mathrm{~kg} \mathrm{ha}^{-1}$ which was statistically similar with days to maturity taken by 6 and $8 \mathrm{~kg} \mathrm{ha}^{-1}$. 


\section{Plant height (cm)}

Data regarding plant height as affected by seed rates and varieties are presented in Table 1. Plant height of canola was significantly affected by seed rates and varieties while $\mathrm{S} \times \mathrm{V}$ was non-significant. Maximum plant height $\left(\begin{array}{lll}149 & \mathrm{~cm}\end{array}\right)$ was recorded in plots where $10 \mathrm{~kg} \mathrm{ha}^{-1}$ seed rate was used, while minimum plant height (138 $\mathrm{cm})$ was recorded in plots in which $4 \mathrm{~kg} \mathrm{ha}^{-1}$ seed rate was used which was statistically similar to that produced by $6 \mathrm{~kg} \mathrm{ha}^{-1}$ (141 $\mathrm{cm})$. In case of varieties, taller plants were produced by Durr-e-NIFA $(145 \mathrm{~cm})$ as compared to Zahoor Swati which produced shorter plants $(141 \mathrm{~cm})$.

\section{0-grains weight $(\mathrm{g})$}

Thousand grains weight of canola was significantly affected by seed rates and varieties while their interaction did not affect 1000-grains weight significantly (Table 2). In seed rates, maximum 1000grains weight $(3.92 \mathrm{~g})$ was found in plots where $4 \mathrm{~kg} \mathrm{ha}^{-1}$ seed rate was used, while minimum 1000-grains weight (3.30 g) was found in $10 \mathrm{~kg} \mathrm{ha}^{-1}$ which was statistically similar with that of $8 \mathrm{~kg} \mathrm{ha}^{-1}(3.51 \mathrm{~g})$. In case of varieties, Durr-e-NIFA gave maximum grain weight $(3.69 \mathrm{~g})$ as compared to Zahoor Swati $(3.51 \mathrm{~g})$.

Table 2. Thousand grains weight, biological yield and grain yield of canola as affected by seed rates and varieties

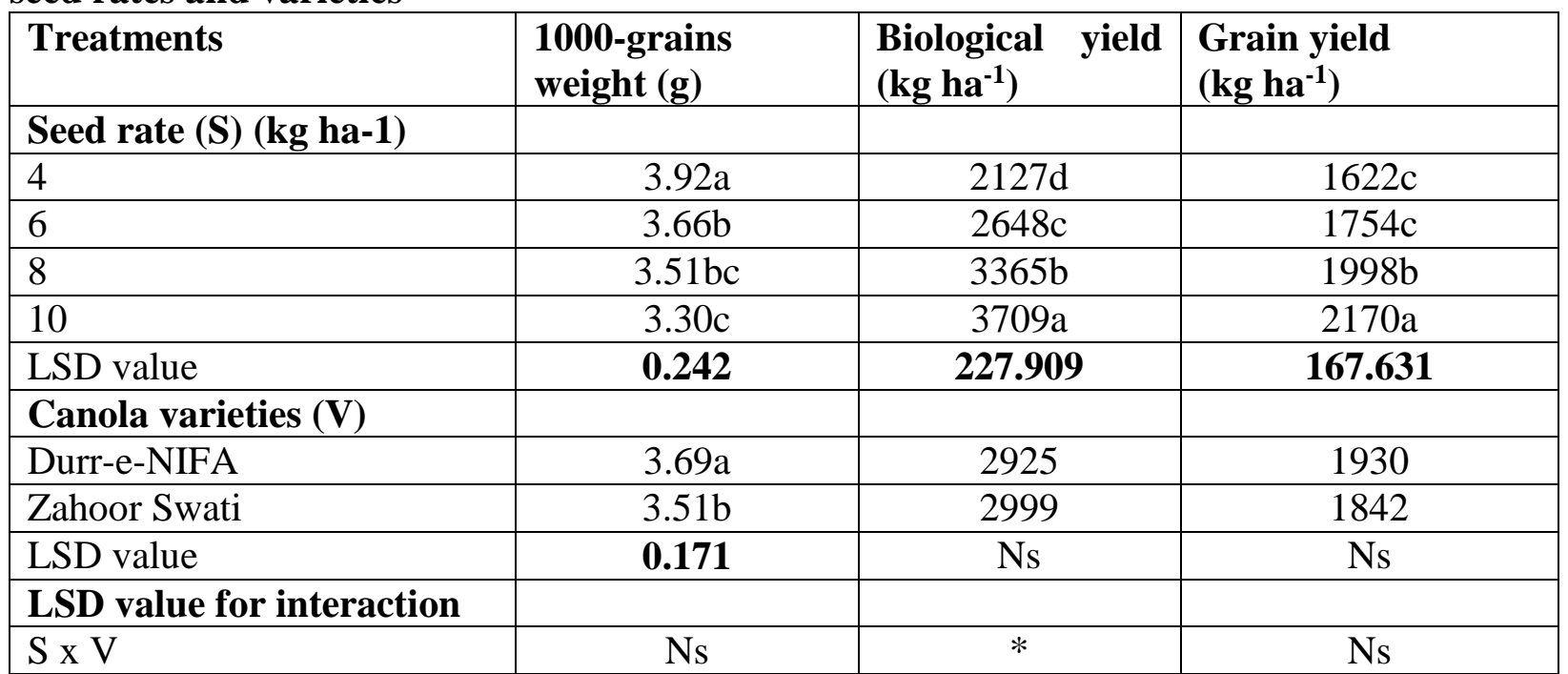

Means in the same category followed by different letters are significantly different at $\mathrm{P} \geq 0.05$ levels. $*=$ significant. Ns = non-significant.

\section{Biological yield ( $\left.\mathrm{kg} \mathrm{ha}^{-1}\right)$}

Biological yield of canola varieties varied considerably by seed rates and $\mathrm{S} \times \mathrm{V}$ (Table 2). Among seed rates maximum biological yield $\left(3709 \mathrm{~kg} \mathrm{ha}^{-1}\right)$ was produced by $10 \mathrm{~kg}$ $\mathrm{ha}^{-1}$ while minimum biological yield $(2127$ $\mathrm{kg} \mathrm{ha}^{-1}$ ) was produced by seed rate of $4 \mathrm{~kg}$ $\mathrm{ha}^{-1}$. Based on the interaction between seed rates and varieties, variety Durr-e-NIFA produced maximum biological yield (3751 $\mathrm{kg} \mathrm{ha}^{-1}$ ) when sown at the seed rate of $10 \mathrm{~kg}$ ha $^{-1}$ (Figure 1). 


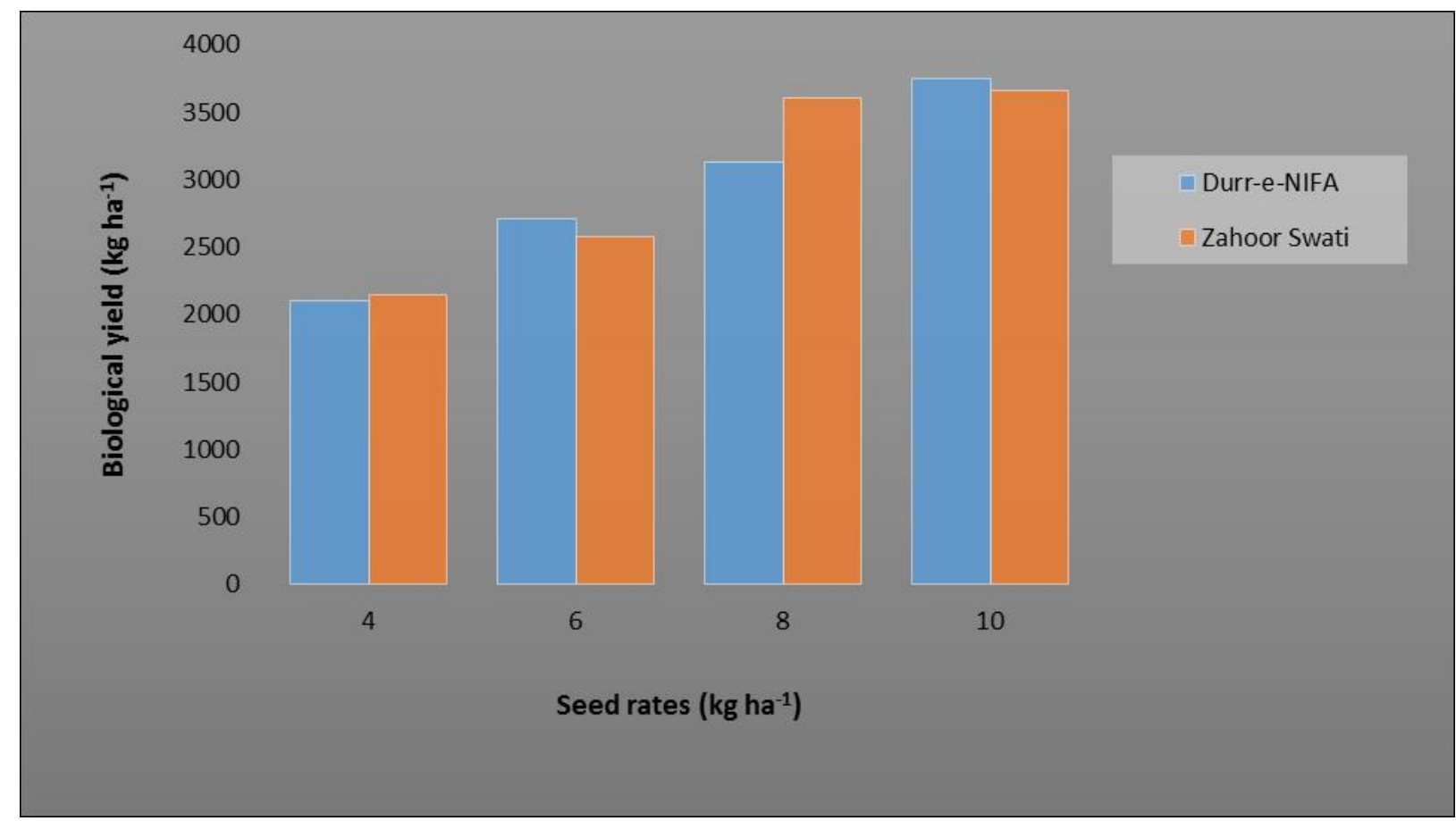

Figure 1. Biological yield ( $\left.\mathrm{kg} \mathrm{ha}^{-1}\right)$ of canola as affected by seed rates and varieties

\section{Grain yield ( $\left.\mathrm{kg} \mathrm{ha}^{-1}\right)$}

Table 2 shows data about grain yield of canola varieties as affected by seed rates. It is evident from statistical analysis that seed rate significantly affected grain yield of canola, however the interaction of varieties and seed rates was found non-significant. Among seed rates, maximum grain yield $\left(2170 \mathrm{~kg} \mathrm{ha}^{-1}\right)$ was recorded with the seed rate of $10 \mathrm{~kg} \mathrm{ha}^{-1}$ while minimum grain yield (1622 $\mathrm{kg} \mathrm{ha}^{-1}$ ) was produced by $4 \mathrm{~kg} \mathrm{ha}^{-1}$ seed rate.

\section{Discussion}

Emergence $\mathrm{m}^{-2}$ of canola was significantly affected by seed rates and varieties. Higher emergence $\mathrm{m}^{-2}$ was recorded with higher seed rate as compared to lower seed rate. Maximum emergence $\mathrm{m}^{-2}$ was recorded in plots with the seed rate of $10 \mathrm{~kg} \mathrm{ha}^{-1}$. The effect of seed rate on the emergence $\mathrm{m}^{-2}$ of canola might be due to more seedlings emerged due to higher number of seeds sown. These results are in line with those of [17] who concluded that increasing seeding rate increased emergence in canola. In case of varieties, maximum emergence ${ }^{-2}$ was observed in Zahoor Swati as compared to Durr-e-NIFA. The difference of varieties for emergence $\mathrm{m}^{-2}$ might be due to the genetic variations between them. Seed rates significantly affected days to physiological maturity of canola while varieties and $\mathrm{S} \times \mathrm{V}$ were found non-significant for their effect on days to maturity. Plots treated with higher seed rates took more days to maturity than the lower seed rates. Maximum days to maturity were taken by plots of $10 \mathrm{~kg} \mathrm{ha}^{-1}$ seed. Similar results were found by Inamullah et al. [9] who stated that higher seed rates of canola took more days to maturity. Plant height also increased with increase in seed rate. Seed rate of $10 \mathrm{~kg} \mathrm{ha}^{-1}$ produced taller plants. These results are similar to those reported by Karamzadeh et al. [10]. In case of varieties, Durr-e-NIFA resulted in higher plant height than that of Zahoor Swati. The reason might be the genetic variations between the varieties. Our results are in line with [18] who stated that there was significant difference for plant height among different varieties. Thousand grains weight of canola significantly 
affected by seed rates and varieties. In case of seed rates, maximum 1000-grains weight was observed with the seed rate of $4 \mathrm{~kg} \mathrm{ha}^{-1}$. Higher seed rate had low grain weight which might be due to the fact that competition among plants increases with higher plant density. Lower seed rate resulted in higher 1000-grains weight which might be due to low competition for resources among the plants which resulted to increase the grain weight. These results are in line with [19]. In case of varieties, Durr-e-NIFA gave more 1000-grains weight than that of Zahoor Swati. It might be due to the difference in the genetic make-up of the varieties. Biological yield of canola significantly varied by various seed rates and maximum biological yield was produced by the plots seeded with $10 \mathrm{~kg}$ seed ha ${ }^{-1}$. Biological yield increased with increasing seed rate due to higher density. Similar results were found by Ogrodowczyk and Wawrzyniak [20] who stated that with an increase in seed rate, higher biological yield was harvested in canola crop. Grain yield of canola was significantly affected by seed rates. Maximum grain yield was recorded with 10 $\mathrm{kg} \mathrm{ha}{ }^{-1}$ while. [20, 21] reported the same results that increase in yield is strongly correlated with increase in yield components such as siliques plant ${ }^{-1}$, grains silique ${ }^{-1}$ etc.

\section{Conclusions and recommendations}

It was concluded that seed rate of $10 \mathrm{~kg} \mathrm{ha}^{-1}$ gave maximum performance in terms of emergence $\mathrm{m}^{-2}$, plant height, biological yield and grain yield. The variety Durr-e-NIFA performed better in terms of plant height and1000-grains weight. So, it is recommended that variety Durr-e-NIFA should be grown at the seed rate of $10 \mathrm{~kg} \mathrm{ha}^{-}$

1 to get the highest biological and grain yield.

\section{Authors' contributions}

Conceived and designed the experiments: B Khan, M Islam \& M Jawad, Performed the experiments: M Jawad, J Ali, M Ishaq \& A
Rehman, Data collection and field inspections: M Jawad, Z Hussain, M Islam, WA Shah, R Amin, Anjum \& B Khan, Statistical Analysis of the data: M Islam, Anjum \& Z Hussain, Contributed reagents/ materials/ analysis tools: R Amin \& WA Shah, Wrote the paper: M Islam \& M Jawad.

\section{References}

1. Wiedenhoeft M \& Bharton BA (1994). Management and environment effects on Brassica forage quality. Agron J 86: 227237.

2. Amin R \& Khalil SK (2005).Effect of pre- and post-emergence herbicides and row spacing on canola. Sarhad J Agric 21: 165-170.

3. Banuelos GS, Bryla DR \& Cook CG (2002). Vegetative production of kenaf and canola under irrigation in central California. Industrial Crops \& Products 15: 237-245.

4. Muhammad N, Cheema MA, Wahid MA, Ahmad N \& Zaman M (2007). Effect of source and method of nitrogen fertilizer application on seed yield and quality of canola (Brassica napusL.). Pak J Agri Sci 44(1): 74-78.

5. Wahid MA, Cheema MA, Malik MA \& Ashraf M (2009). Comparative performance of canola hybrids in response to different phosphatic fertilizers. Int J Agric \& Bio 11(3): 307309.

6. Starner DE, Hamama AA \& Bhardwaj L (1999). Canola oil yield and quality as affected by production practices in Virginia, In: Janick J. (Ed.). Perspectives of new crops and new uses. ASHS Press Alexandria 254-256.

7. MINFAL (2013). Agriculture statistics of Pakistan. Ministry for food, Agriculture, and livestock. Eco. Wing, Government of Pakistan, Islamabad.

8. Diepenbrock W (2000). Yield analysis of winter oilseed rape. A review. J Field Crops Res 67: 35-49. 
9. Inamullah, Khan B, Din M, Siddiq M, Khan AA, Munir A, Azeem K \& Haq GU (2013). Effect of various seed rates and nitrogen levels on the productivity of late sown brassica. Sarhad J Agric 29(4): 503-509.

10. Karamzadeh A, Mobasser HR, Ramee HR \& Malidarreh AG (2010). Effects of nitrogen and seed rates on yield and oil content of canola. Am-Euras. J Agric \& Environ Sci 8(6): 715-721.

11. Etemadi ME, Daliri MS \& Mousavi AA (2013). The effect of seeding rate on yield and yield component of three canola varieties in Iran North. Advances in Env Bio 7(1): 198-200.

12. Rad AHS, Abbasian A \& Aminpanah H (2014). Seed and oil yields of rapeseed (Brassica napus L.) cultivars under irrigated and non-irrigated conditions. $J$ Anim Plant Sci 24(1): 204-210.

13. Sana MA, Ali M, Malik A, Saleem MF \& Rafiq M (2003). Comparative yield potential and oil contents of different canola cultivars (Brassica napus L.). Pak J Agron 2(1): 1-7.

14. Khehra MK \& Singh P (1988). Sensitivity and performance of some canola (Brassica napus L.) genotypes in stress and non-stress environments. Crop Improvement Ind 15: 209-211.

15. Khoshanazar PR, Ahmadi MR \& Ghanndha MR (2000). A study of adaptation and yield capacity of rapeseed (Brassica napus L.) cultivars and tines. Iranian J Agric Sci 31: 341352.

16. Steel RGD \& Torrie JH (1984). Principles and procedure of statistics 2 nd edMc, Graw Hill, New York.

17. Brandt SA, Malhi, Ulrich D, Lafond GP, Kutcher HR \& Johnston AM (2007). Seeding rate, fertilizer level and disease management effects on hybrid versus open pollinated canola (Brassica napus L.). Can J Plant Sci 87: 255-266.

18. Shahin Y \& Valiollah R (2009). Effects of row spacing and seeding rates on some agronomical traits of spring canola (Brassica napus L.) cultivars. J Cent Eur Agric 10(1): 115-122.

19. Arslan N (1994). Effect of sowing date and plant density on seed yield of Nigel (Nigella damascena L.). J Field Crops Cent Res Inst 3: 1-2.

20. Ogrodowczyk M \& Wawrzyniak M (2004). Adoption and path-coefficient analysis for assessment of relationship and inter-relationship of yield and yield parameters of winter oilseed rape. Rosliny Oleiste 25(2): 479-491.

21. Malidarreh AG (2010). Effects of nitrogen rates and splitting on oil content and seed yield of canola. Am-Euras. $J$ Agric \& Environ Sci 8(2): 161-166. 